MaRia TKOCZ

Uniwersytet Śląski

\title{
Efekty restrukturyzacji górnictwa węgla kamiennego w Polsce
}

Jednym z najtrudniejszych do rozwiązania problemów w okresie transformacji gospodarki był problem restrukturyzacji górnictwa węgla kamiennego, którego głównym celem było doprowadzenie do jego rentowności i funkcjonowania zgodnie z zasadami gospodarki rynkowej. Problem ten próbowano rozwiązać w ramach kolejnych programów rządowych: „Restrukturyzacja górnictwa węgla kamiennego w Polsce” (1993), „Górnictwo węgla kamiennego, polityka państwa i sektora na lata 1996-2000” (1996), „Reforma górnictwa węgla kamiennego w Polsce w latach 1998-2002” (1998), „Program likwidacji zdolności produkcyjnych górnictwa węgla kamiennego w latach 1998-2002” (1999), „Restrukturyzacja górnictwa węgla kamiennego w latach 2004-2006 oraz strategia na lata 2007-2010" (2004).

Programy te, głównie ze względu na brak konsekwencji w ich realizacji, nie doprowadziły do zrealizowania podstawowego celu jakim było osiagnięcie rentowności całej branży. Spowodowały jednak wiele zmian zarówno w skali makro- jak i mikroekonomicznej. Zmiany te oraz rezultaty przeprowadzonych reform w górnictwie są przedmiotem niniejszego artykułu.

Zagadnienia dostosowania górnictwa węgla kamiennego do wymogów kształtującej się gospodarki wolnorynkowej były przedmiotem licznych studiów grona naukowców i praktyków związanych z Głównym Instytutem Górnictwa oraz Państwową Agencją Węgla Kamiennego, przekształconą w 1996 r. w Państwową Agencję Restrukturyzacji Górnictwa [m.in. Bąk, Majewski 1995; Dilling 1993; Karbownik, Pawełczyk, Morawski 1996; Lisowski 1996; Zabierowski 1996]. Większość autorów tych prac koncentrowało się na wybranych aspektach restrukturyzacji, nie dając odpowiedzi na pytanie czy dotychczasowe działania są zgodne z zamierzonymi celami restrukturyzacji górnictwa.

Wybrane zagadnienia restrukturyzacji górnictwa węgla kamiennego były także przedmiotem zainteresowań geografów [Kortus, Adamus 1992; Makieła 2002; Pakuła 1992, 1997, 2003; Pukowska-Mitka, Tkocz 1992; Riley, Tkocz 1998, 1999; Tkocz 1989, 1996, 1998, 2001), którzy zwracali szczególną uwagę na rolę górnictwa w strukturze gospodarki Polski oraz regionu katowickiego, a także przemiany przestrzenne. 


\section{UWARUNKOWANIA RESTRUKTURYZACJI GÓRNICTWA WĘGLA KAMIENNEGO}

Dotychczasowe programy restrukturyzacji górnictwa węgla kamiennego jako podstawowe cele stawiały sobie dostosowanie górnictwa do warunków gospodarki rynkowej i międzynarodowej konkurencji. Cele te górnictwo miało osiąnąć poprzez zmniejszenie zdolności produkcyjnych drogą likwidacji kopalń i redukcji zatrudnienia. Po przystąpieniu Polski do Unii Europejskiej zaistniała konieczność uwzględnienia innych czynników kształtujących proces restrukturyzacji.

Po pierwsze ważnym zadaniem programu restrukturyzacji stało się uzyskanie pomocy ze środków UE. Pomoc ta jest niezbędna dla wprowadzenia zmian w strukturze zużycia energii pierwotnej, która w Polsce (tab. 1) odbiega od struktury zapotrzebowania na energię pierwotną w wysoko rozwiniętych krajach europejskich, gdzie zapotrzebowanie na energię w $41 \%$ jest pokrywane przez ropę naftową, w $22 \%$ przez gaz, w $16 \%$ przez węgiel kamienny i brunatny, w $15 \%$ przez energię jądrową i w $6 \%$ przez odnawialne źródła energii (Plany 2004). W ostatnich latach w Polsce nastąpiły w tym zakresie niewielkie zmiany (tab. 1) wyrażające się wzrostem udziału ropy naftowej i gazu ziemnego, głównie kosztem zmniejszenia udziału węgla kamiennego.

Tabela 1. Struktura zużycia energii pierwotnej w Polsce w latach 1990-2002 (w \%)

\begin{tabular}{|l|r|r|r|}
\hline \multirow{2}{*}{\multicolumn{1}{|c|}{ Paliwo pierwotne }} & \multicolumn{3}{|c|}{ lata } \\
\cline { 2 - 4 } & 1990 & 2000 & 2002 \\
\hline wegiel kamienny & 63,9 & 50,9 & 51,7 \\
węgiel brunatny & 13,4 & 13,3 & 12,7 \\
ropa naftowa & 12,6 & 20,2 & 19,9 \\
gaz ziemny & 8,9 & 11,0 & 10,8 \\
energia odnawialna i odpadowa & 1,2 & 4,6 & 4,9 \\
\hline Ogółem & 100,0 & 100,0 & 100,0 \\
\hline
\end{tabular}

Źródło: Plany dostępu do zasobów węgla kamiennego w latach 2004-2006, Ministerstwo Gospodarki i Pracy, 2004

O dominującej roli węgla kamiennego świadczy również udział tego paliwa w produkcji energii elektrycznej w Polsce w 2002 r. (tab. 2).

Tabela 2. Struktura produkcji energii elektrycznej w Polsce i krajach UE w 2002 r. (w \%)

\begin{tabular}{|l|c|r|}
\hline \multicolumn{1}{|c|}{ Rodzaj paliwa } & Polska & \multicolumn{1}{c|}{ UE } \\
\hline wegiel kamienny & 55 & 17,5 \\
weggiel brunatny & 37 & 7,4 \\
woda & 3 & 13,6 \\
paliwa ciekłe & 2 & 6,0 \\
gaz ziemny & 1 & 17,5 \\
energia jądrowa & - & 33,0 \\
inne & 2 & 5,0 \\
\hline Ogółem & 100 & 100,0 \\
\hline
\end{tabular}

Źródło: jak w tab. 1 
Ta struktura również odbiega od struktury produkcji energii elektrycznej w krajach Unii Europejskiej (tab. 2). Zaletą węglowej struktury bilansu energetycznego jest bazowanie na najtańszych nośnikach. Dominujący udział pozyskiwanych w kraju paliw stałych w strukturze zużycia energii pierwotnej i produkcji energii elektrycznej zapewnia bezpieczeństwo energetyczne na wysokim i stabilnym poziomie oraz ogranicza obciążenie bilansu handlowego kosztem importu energii.

Źródła energii odnawialnej (wykorzystanie biomasy, energetyka wodna, wiatrowa, słoneczna oraz energia geotermalna) nie mają aktualnie większego znaczenia dla bezpieczeństwa energetycznego Polski. Jednak ich wykorzystanie poprawia bezpieczeństwo energetyczne w skali lokalnej i przyczynia się do poprawy zaopatrzenia w energię, szczególnie na terenach o słabo rozwiniętej strukturze energetycznej.

Istotna rola węgla kamiennego w zaspokajaniu potrzeb energetycznych Polski zdeterminowana jest zasobami tego nośnika energii. W perspektywie najbliższych lat, mimo dotychczasowych przemian energetycznych (spadek zużycia węgla kamiennego i brunatnego, wzrost zużycia ropy naftowej, gazu ziemnego oraz energii odnawialnej i odpadowej) oraz stopniowego obniżania energochłonności gospodarki, Polska nadal pozostanie krajem o unikatowej w skali międzynarodowej strukturze zużycia nośników energii pierwotnej. Udział węgla kamiennego i brunatnego w pozyskaniu energii elektrycznej nie ulegnie w stosunku do obecnego stanu zmianom i utrzymywał się będzie na tym samym poziomie (ok. 92\%). W perspektywie najbliższych lat dominująca pozycja węgla kamiennego wśród pierwotnych nośników energii zużywanych dla produkcji energii elektrycznej, z uwagi na fakt, że węgiel będzie miał w dalszym ciągu szczególne znaczenie w kształtowaniu potencjału wytwórczego elektroenergetyki, wydaje się również zapewniona. Zgodnie z szacunkami Międzynarodowej Agencji Energii udział tego surowca w zaspokajaniu potrzeb energetycznych Polski utrzyma się na porównywalnym poziomie nawet do 2020 r. Poza strukturą zużycia nośników energetycznych wpływ na to mają także według Ministerstwa Gospodarki:

- struktura gospodarki, w której nadal znaczny udział mają przemysły energochłonne,

- niższa niż w krajach zachodnich ogólna sprawność systemu energetycznego (niedostateczna sprawność wytwarzania energii elektrycznej i cieplnej, przestarzała infrastruktura, generująca znaczne straty energii),

- wysoki koszt modernizacji oraz zmian technologicznych w energetyce i konieczność rozłożenia ich w czasie,

- nadal stosowane w różnych działach gospodarki i w gospodarstwach domowych nieefektywne technologie i urządzenia oraz maszyny,

- energochłonne budownictwo z dawnych lat, które nie odpowiada obowiązującym dziś standardom współczynnika przenikania ciepła,

- stare energochłonne systemy oświetleniowe występujące zarówno w sektorze komunalno-mieszkaniowym, jak i w przemyśle.

We wszystkich tych dziedzinach następuje stopniowa poprawa, wpływająca na spadek energochłonności. Proces ten jednak musi potrwać wiele lat i wymaga znacznych nakładów finansowych.

Jednocześnie przystąpienie Polski do Unii Europejskiej stworzyło konieczność uwzględnienia w procesie restrukturyzacji faktu, iż Polska jest największym producentem węgla kamiennego spośród państw członkowskich (tab. 3), a także jednym z głównych dostawców węgla do krajów Wspólnoty. Według danych Węglokoksu (2004) w roku 2003 dostawy polskiego węgla do Unii Europejskiej pod względem tonażu znajdowały się na piątym miejscu 
po RPA, Australii, Kolumbii oraz Stanach Zjednoczonych. Zdecydowaną większość eksportu stanowiły dostawy węgla energetycznego, które wyniosły 17,5 mln t, zaś węgla koksowego 2,1 mln t. Głównymi odbiorcami polskiego węgla w UE w 2003 r. były Niemcy $(6,9 \mathrm{mln}$ t), Finlandia (2,1 mln t), Wielka Brytania (2,0 mln t), Austria (1,3 mln t), Francja (1,0 mln t).

Tabela 3. Produkcja węgla kamiennego w Polsce i w Unii Europejskiej oraz import węgla przez wybrane kraje w 2003 r.

\begin{tabular}{|l|c|c|c|c|}
\hline \multirow{2}{*}{ Kraj } & \multicolumn{2}{|c|}{ Wielkość produkcji } & \multicolumn{2}{c|}{ Wielkość importu } \\
\cline { 2 - 5 } & mln t & $\%$ & ogółem & w tym z Polski \\
\hline UE ogółem, & 72 & 100,0 & 180,3 & 19,6 \\
w tym: & & & & \\
Francja & 2 & 3,0 & 18,5 & 1,0 \\
Hiszpania & 13 & 18,0 & 20,0 & - \\
Niemcy & 29 & 40,0 & 35,2 & 6,9 \\
Wielka Brytania & 28 & 39,0 & 32,5 & 2,0 \\
\hline Polska & 100,5 & - & - & - \\
\hline
\end{tabular}

Źródło: jak w tab. 1

Programy restrukturyzacji powinny uwzględniać aktualną sytuację na światowym rynku węgla kamiennego. Utrzymująca się od końca 2003 r. wyjątkowa koniunktura na węgiel związana jest z jednej strony z ograniczeniem w podaży węgla, z drugiej - ze zwiększeniem jego zużycia, także przez odbiorców europejskich. O ile jeszcze w marcu 2003 r. średnia cena węgla energetycznego (o standardowej kaloryczności $6000 \mathrm{kcal} / \mathrm{kg}$ ) w portach Europy zachodniej wynosiła 34,30 USD/t, o tyle w listopadzie $2003 \mathrm{r}$. osiagnęła nie notowany od lat poziom 62,50 USD/t. Od początku 2004 r. utrzymywał się dalszy wzrost i w lipcu 2004 r. cena ta osiągnęła rekordowo wysoki poziom 77,80 USD/t, w listopadzie spadła do 77,70 USD/t (Plany 2004).

Ta korzystna koniunktura na rynku światowym sprawiła, że program dalszej restrukturyzacji na lata 2005-2007 przedstawiono w dwóch wariantach. Model docelowy zakłada konieczność wygaszenia ok. $14 \mathrm{mln}$ t zdolności produkcyjnych oraz zmniejszenie zatrudnienia o 25,5 tys. osób do końca 2006 r., natomiast wariant alternatywny, zakłada zmniejszenie zdolności produkcyjnych o 7,8 mln t oraz zmniejszenie zatrudnienia o 19,5 tys. osób w tym samym okresie. Drugi wariant będzie realizowany w warunkach utrzymania się korzystnej koniunktury oraz stabilnej rentowności przedsiębiorstw górniczych.

\section{EFEKTY RESTRUKTURYZACJI W ZAKRESIE PRODUKCJI WĘGLA KAMIENNEGO}

Podstawowym celem każdego programu restrukturyzacji była redukcja zdolności produkcyjnych górnictwa. Cel ten systematycznie realizowano (ryc. 1). W okresie 1989-2003 wydobycie węgla kamiennego zmniejszyło się z 177,4 mln t do 100,5 mln t, czyli o $77 \mathrm{mln} \mathrm{t}$, co stanowi 43,3\%. Spadek wydobycia nastąpił w prawie wszystkich kopalniach, z wyjątkiem kopalni „Budryk”, uruchomionej w 1994 roku oraz lubelskiej kopalni „Bogdanka”. W związku z redukcją zatrudnienia nastąpiły zmiany struktury wielkościowej kopalń rozpatrywanej według wydobycie (tab. 4). 
Maria TKocz

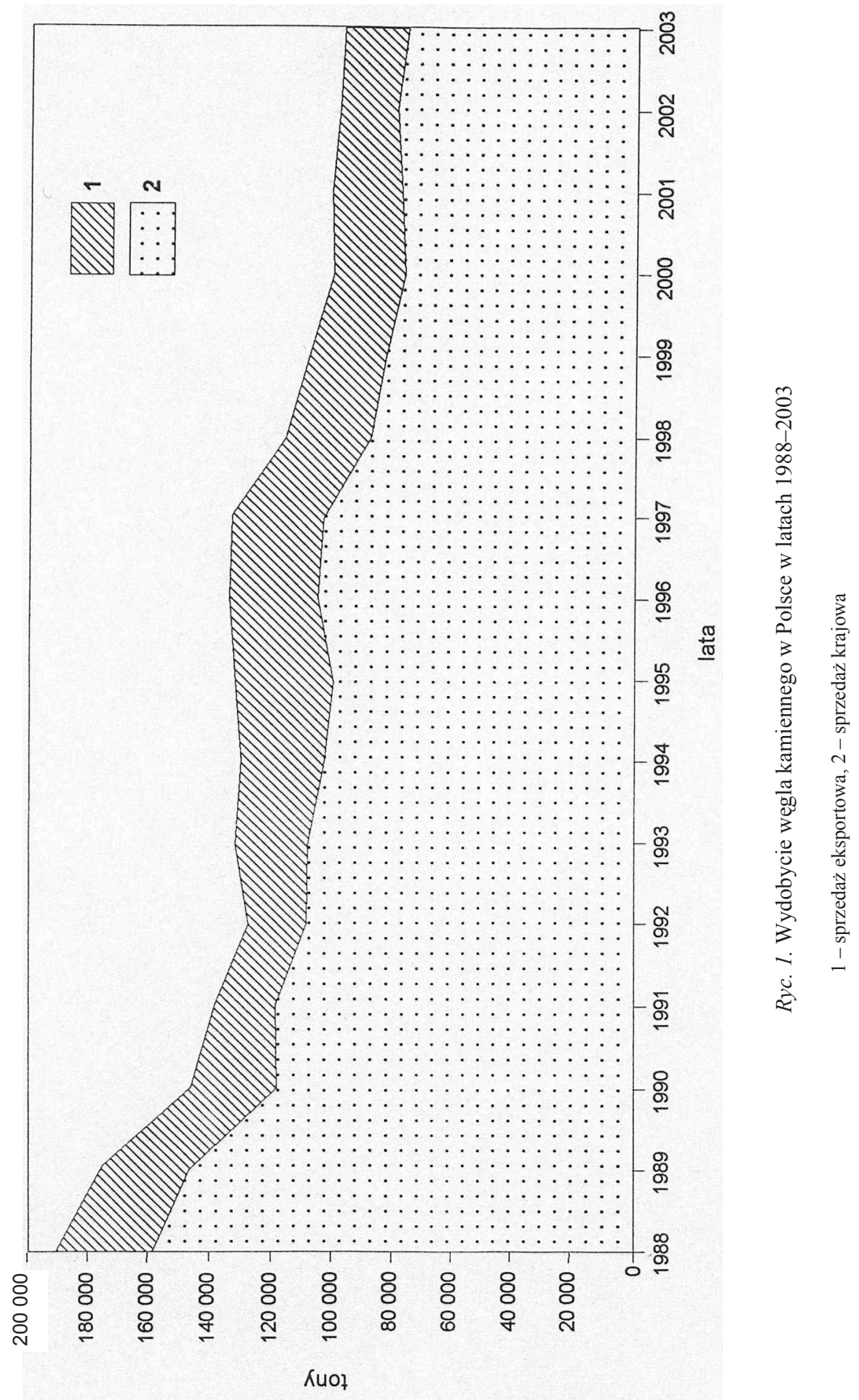


Szczególnie istotny był spadek zarówno liczby, jak i wielkości wydobycia (z 34,8\% do $15,2 \%$ ) w kopalniach dużych o rocznym wydobyciu ponad $4 \mathrm{mln} \mathrm{t}$ (tab. 4).

Tabela 4. Kopalnie węgla kamiennego według wielkości rocznego wydobycia

\begin{tabular}{|l|r|r|r|r|r|r|}
\hline \multirow{2}{*}{$\begin{array}{c}\text { Wydobycie } \\
\text { węgla kamiennego } \\
\text { (mln t) }\end{array}$} & \multicolumn{3}{|c|}{1989} & \multicolumn{3}{c|}{2003} \\
\cline { 2 - 5 } & Liczba & \multicolumn{2}{|c|}{ Wydobycie } & Liczba & \multicolumn{2}{c|}{ Wydobycie } \\
\cline { 3 - 4 } \cline { 6 - 7 } & kopalńn & tys. t & \multicolumn{1}{c|}{$\%$} & kopalń & tys. t & \multicolumn{1}{c|}{$\%$} \\
\hline $0-1$ & 9 & 6671 & 3,8 & 2 & 1054,3 & 1,0 \\
$1-2$ & 17 & 24385 & 13,7 & 13 & 20199,5 & 20,1 \\
$2-3$ & 25 & 60419 & 34,1 & 17 & 43605,3 & 43,4 \\
$3-4$ & 7 & 24083 & 13,6 & 6 & 20417,9 & 20,3 \\
$4-5$ & 7 & 31010 & 17,5 & 2 & 9234,2 & 9,2 \\
$5-6$ & 3 & 15505 & 8,7 & 1 & 6000,0 & 6,0 \\
powyżej 6 & 2 & 15286 & 8,6 & - & - & - \\
\hline Razem & 70 & 177359 & 100,0 & 41 & 100511,2 & 100,0 \\
\hline
\end{tabular}

Źródło: obliczenia własne na podstawie Rocznik statystyczny kopalń 1991, Plan 2004

\section{EFEKTY RESTRUKTURYZACJI ZATRUDNIENIA}

Adaptacja górnictwa do potrzeb gospodarki rynkowej wymaga nie tylko ograniczenia nadmiernego wydobycia, ale także wzrostu wydajności pracy, co wiąże się z koniecznością zmniejszenia zatrudnienia w kopalniach. W latach 1989-2003 w związku ze spadkiem liczby pracujących w kopalniach z 415740 do 135704 (ryc. 2), nastąpiły zmiany struktury wielkościowej kopalń (tab. 4).

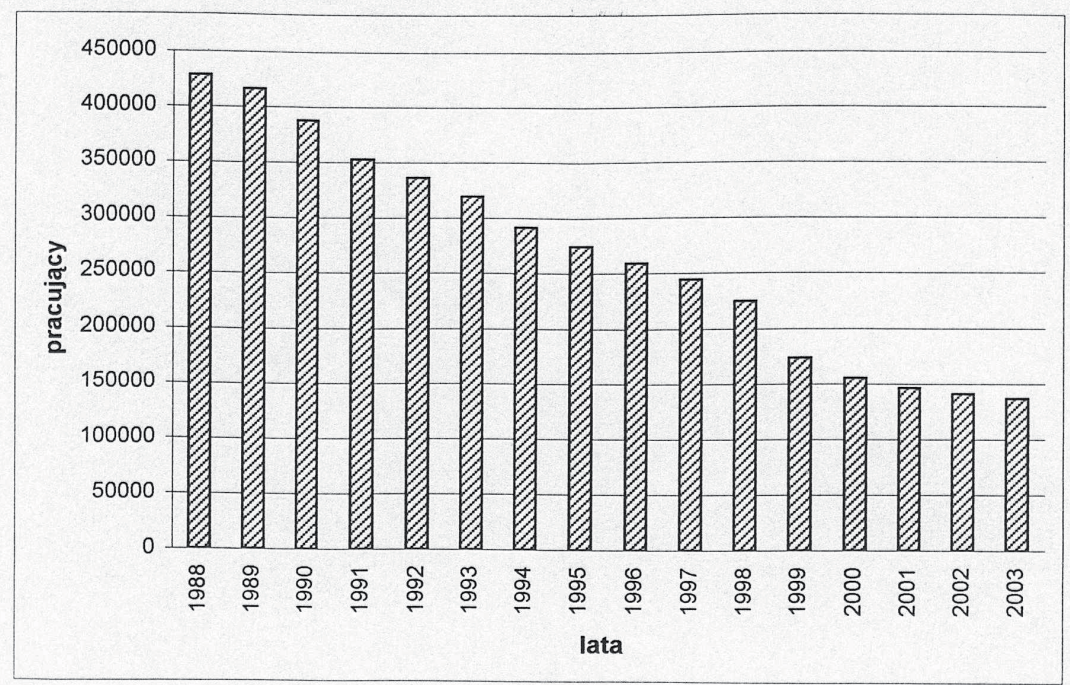

Ryc. 2. Pracujący w górnictwie węgla kamiennego w latach 1988-2003 
Najwyższy spadek pracujących (4,0-5,0 tys.) nastąpił w kopalniach gigantach, które koncentrowały powyżej 10000 pracujących („Piast”, „Ziemowit”, „Zabrze-Bielszowice”, „Knurów”). Łącznie udział pracujących w kopalniach dużych, powyżej 5000 osób, obniżył się z 70,3\% w 1989 r. do 13,3\% w 2003 r. Dominująca grupą w strukturze wielkościowej kopalń pozostały kopalnie, w których pracowało od 3501-5000 osób (tab. 4). Ich liczba zmniejszyła się z 23 w 1989 r. do 15 w 2003 r. W latach 1989-2003 średnia liczba pracujących w jednej kopalni zmniejszyła się z 5939 do 3310 osób, zaś wielkość wydobycia na 1 pracującego wzrosła z 427 do 741 ton.

Tabela 4. Kopalnie węgla kamiennego według liczby pracujących

\begin{tabular}{|c|c|c|c|c|c|c|}
\hline \multirow{3}{*}{\begin{tabular}{|c|} 
Kopalnie \\
według liczby \\
pracujących
\end{tabular}} & \multicolumn{3}{|c|}{1989} & \multicolumn{3}{|c|}{2003} \\
\hline & \multirow{2}{*}{$\begin{array}{l}\text { Liczba } \\
\text { kopalń }\end{array}$} & \multicolumn{2}{|c|}{ Pracujący } & \multirow{2}{*}{$\begin{array}{l}\text { Liczba } \\
\text { kopalń }\end{array}$} & \multicolumn{2}{|c|}{ Pracujący } \\
\hline & & osoby & $\%$ & & osoby & $\%$ \\
\hline $0-2000$ & - & - & - & 5 & 7282 & 5,4 \\
\hline $2001-3500$ & 7 & 22768 & 5,5 & 18 & 47911 & 35,3 \\
\hline $3501-5000$ & 23 & 100582 & 24,2 & 15 & 62354 & 46,0 \\
\hline $5001-6500$ & 15 & 86009 & 20,7 & 2 & 10372 & 7,6 \\
\hline $6501-8000$ & 11 & 76844 & 18,5 & 1 & 7785 & 5,7 \\
\hline $8001-9500$ & 10 & 86941 & 20,9 & - & - & - \\
\hline $9501-11000$ & 3 & 31405 & 7,5 & - & - & - \\
\hline pow. 11000 & 1 & 11191 & 2,7 & - & - & - \\
\hline Razem & 70 & 415740 & 100,0 & 41 & 135704 & 100,0 \\
\hline
\end{tabular}

Źródło: obliczenia własne na podstawie Rocznik statystyczny kopalń 1991, Plan 2004

\section{EFEKTY RESTRUKTURYZACJI ORGANIZACYJNEJ}

Celem restrukturyzacji organizacyjnej było stworzenie struktur organizacyjnych działających zgodnie z kodeksem handlowym. W 1990 r. w pierwszym etapie restrukturyzacji kopalnie węgla kamiennego uzyskały status przedsiębiorstw państwowych i pełną samodzielność, która nie przyniosła jednak oczekiwanej poprawy w ich funkcjonowaniu. W drugim etapie restrukturyzacji w 1993 r. utworzono 7 węglowych spółek akcyjnych, w tym sześć w formie koncernów (Bytomska, Rudzka, Gliwicka, Nadwiślańska, Rybnicka, Jastrzębska Spółka Węgla) i jedną w formie holdingu (Katowicki Holding Węglowy) (ryc. 3).

Jednocześnie w odniesieniu do trwale nierentownych kopalń rozpoczęto proces likwidacji. Zastosowano dwie strategie: pierwsza polegała na likwidacji bezpośredniej, czyli postawienie zakładu w stan likwidacji, druga - na likwidacji pośredniej, czyli łączeniu kopalń przewidzianych do likwidacji z kopalniami mającymi perspektywy dalszego funkcjonowania. W ramach pierwszej strategii z kopalni postawionej w stan likwidacji, w niektórych przypadkach warunkowanych wielkością złoża, wydzielono spółkę z o.o., której celem było wyeksploatowanie istniejących zasobów. Taki tryb postępowania zastosowano głównie w kopalniach Bytomskiej Spółki Węglowej. 


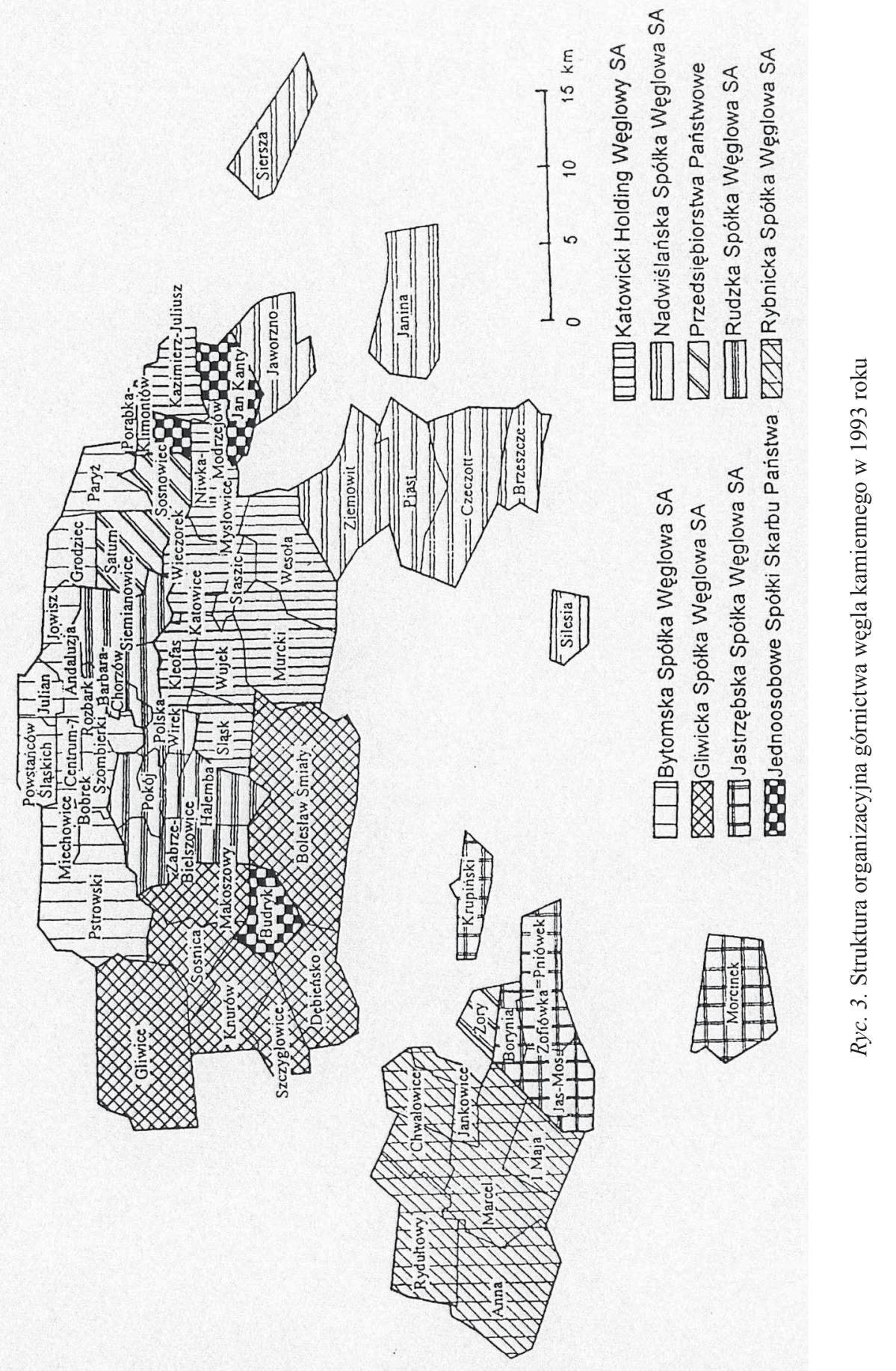


Kolejne zmiany organizacyjne nastapiły w 2003 r. 1 lutego 2003 r. na bazie przedsiębiorstw spółek węglowych Gliwickiej, Rudzkiej, Nadwiślańskiej i Rybnickiej oraz zakładów górniczych - jednoosobowych spółek z o.o. Bytomskiej Spółki Węglowej S.A. utworzono Kompanię Węglową z siedzibą w Katowicach. W jej skład weszły 23 kopalnie: „Bielszowice”, „Polska-Wirek”, „Bolesław Śmiały”, „Makoszowy”, „Szczygłowice”, „Janina”, „Silesia”, „Rydułtowy”, „Marcel”, „Jankowice”, „Halemba”, „Pokój”, „Sośnica”, „Knurów”, „Brzeszcze”, „Piast”, „Ziemowit”, „Anna”, „Chwałowice”, ZG „Piekary”, ZG „Bytom” II, ZG „Bytom” III oraz ZG „Centrum” (ryc. 4).

Katowicki Holding Węglowy został przekształcony w Katowicką Grupę Kapitałową, w skład której weszło 8 kopalń: „Katowice-Kleofas”, „Wieczorek”, „Staszic”, „Murcki”, „Wujek”, „Mysłowice”, „Wesoła” i „Śląsk” oraz kopalnia-spółka „Kazimierz-Juliusz” utworzona na bazie majątku KHW S.A.

Nie zmieniła swej formy działalności Jastrzębska Spółka Węglowa S.A. powstała 1 kwietnia 1993 r. jako jednoosobowa spółka Skarbu Państwa z siedzibą w JastrzębiuZdroju. W skład JSW wchodzi 5 kopalń: „Borynia”, „Jas-Mos”, „Krupiński”, „Pniówek” i „Zofiówka” (ryc. 4). Jest ona największym producentem węgla koksowego nie tylko w Polsce, ale i w całej Unii Europejskiej.

Oprócz wymienionych organizacji gospodarczych dwie kopalnie: KWK „Budryk” S.A. i Lubelski Węgiel „Bogdanka” S.A. funkcjonują samodzielnie, jedna kopalnia ZGE „SobieskiJaworzno" III Sp. z o.o. działa w ramach Południowego Koncernu Energetycznego, a jedna „Silteck” Sp. z o.o. jest kopalnią prywatną.

W pierwszym półroczu 2004 r. przeprowadzono dalsze zmiany organizacyjne mające na celu uproszczenie struktury organizacyjnej sektora:

- z dniem 01.03.2004 r. połączono należące do Kompanii Węglowej S.A. kopalnie jednoruchowe „Anna” oraz „Rydułtowy” w jedną kopalnię dwuruchową „RydułtowyAnna",

- z dniem 01.04.2004 r. Kompania Węglowa S.A. wniosła kopalnię „Janina” do nowo utworzonego podmiotu i od tego dnia kopalnia ta funkcjonuje jako Zakład Górniczo-Energetyczny „Janina” Sp. z o.o. w ramach Południowego Koncernu Energetycznego.

W artykule przedstawiono tylko niektóre rezultaty restrukturyzacji górnictwa węgla kamiennego, ograniczając zakres pracy do efektów ilościowych. Pominięto całą sferę zagadnień wpływu restrukturyzacji na gospodarkę regionalną oraz lokalną, a także kwestie finansowe, które w różnorodnych dokumentach i sprawozdaniach nie są jednoznacznie określone i wymagają odrębnego opracowania.

W konkluzji należy stwierdzić, że dokonane w okresie 1989- 2003 zmiany w górnictwie zbliżają je do funkcjonowania według zasad gospodarki rynkowej. Przejawem tego są zmiany organizacyjne, w wyniku których zredukowano „nadbudowę” administracyjną 5 spółek węglowych, a w ich miejsce utworzono jedną Kompanię Węglową. Oprócz niej utrzymano dwie dotychczasowe struktury, tj. Katowicki Holding Węglowy S.A., funkcjonujący jako Katowicka Grupa Kapitałowa, oraz Jastrzębską Spółkę Węglową S.A. ze względu na odmienny typ produkcji węgla. 


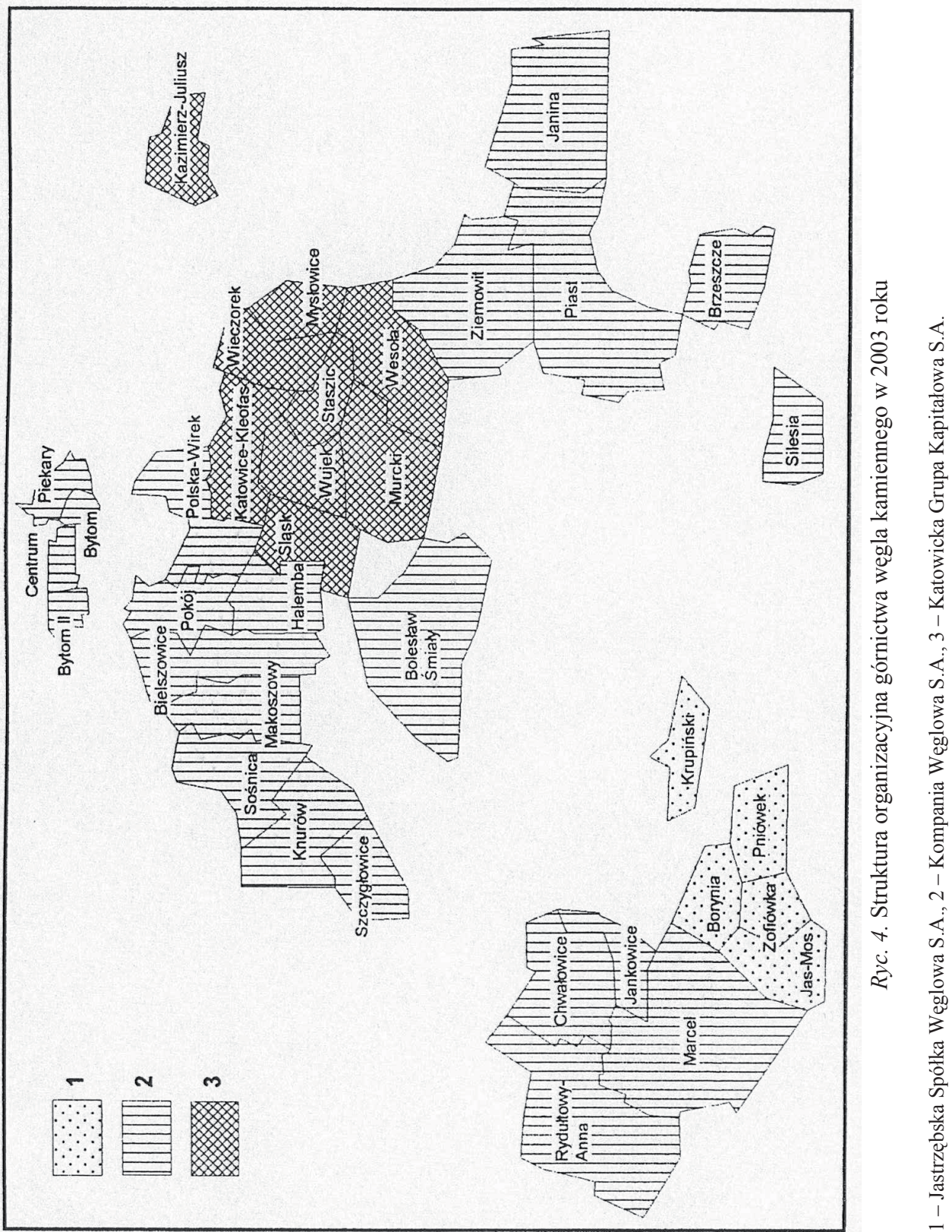


W okresie 1989-2003 zlikwidowano 29 kopalń, zwłaszcza w północnej i wschodniej części zagłębia węglowego, tj. na obszarach najdłużej eksploatowanych i posiadających złoża pod obszarami silnie zurbanizowanymi, często w filarach ochronnych (Bytom, Chorzów, Gliwice, Zabrze, Będzin, Dąbrowa Górnicza, Sosnowiec). Konsekwencją był spadek wydobycia z 177,4 mln t do 100,5 mln t oraz liczby pracujących z 415,7 tys. do 135,7 tys. osób.

Na lata 2004-2006 przewiduje się dalszą redukcję wydobycia w zależności od koniunktury światowej w wysokości $14 \mathrm{mln}$ t rocznie bądź 7,8 mln t rocznie.

W planie zamknięcia kopalń w latach 2004-2007 przewidziane są następujące zakłady:

- spośród kopalń Kompanii Węglowej S.A. - ZG „Bytom” II oraz KWK „PolskaWirek",

- spośród kopalń Katowickiego Holdingu Węglowego S.A. - KWK „KatowiceKleofas".

Częściowa likwidacja zdolności produkcyjnych obejmuje kopalnie, w stosunku do których prowadzone będą procesy łączenia, czyli kopalnię „Anna” i „Rydułtowy”, kopalnię „Brzeszcze” i „Silesia”, kopalnię „Bytom” III i „Centrum” oraz kopalnie „Halemba” i „Pokój”.

\section{Literatura}

Bąk M., Majewski J. 1995, Przebieg procesu prywatyzacji kopalń wegla kamiennego, Biuletyn PAWK, nr 10(2), s. 4-9

Dilling R. 1993, Zadania Spółek Węlowych w zakresie technicznej restrukturyzacji górnictwa węgla kamiennego, „Przegląd Górniczy”, nr 9, s. 15-18

Karbownik A., Pawełczyk E., Morawski E. 1996, Restrukturyzacja górnictwa węgla kamiennego w Polsce w latach 1994-1995, „Wiadomości Górnicze”, nr 6, s. 250-263

Kortus B., Adamus J. 1992, Ocena przemian strukturalnych w Okręgu Górnoślaskim i Krakowskim, Folia Geographica. Series Oeconomica, vol. XXIV, Wrocław-Warszawa, s. 13-35

Lisowski A. 1996, Górnictwo węla kamiennego w Polsce, „Śląsk”, Katowice

Makieła Z. 2002, Wyniki realizacji programów restrukturyzacji górnictwa węla kamiennego po 1989 r., [w:] Problemy transformacji struktur przemysłowych, red. Z. Zioło, Prace Komisji Geografii Przemysłu PTG, nr 4, Warszawa-Kraków-Rzeszów, s. 57-65

Pakuła L. 1992, Postęyy restrukturyzacji przemysłu $w$ wybranych gałęziach okręgu górnoślaskiego, częstochowskiego i bielskiego, Folia Geographica. Series Geographica-Oeconomica, vol. XXIV, Wrocław-Warszawa-Kraków, s. 37-51

Pakuła L. 1997, Zmiany strukturalne i proces transformacji przemysłu Górnoślaskiego Okręu przemystowego, Zeszyty IG i PZ PAN, nr 46, s. 53-93

Pakuła L. 2003, Tendencje restrukturyzacji przemystu Górnoślaskiego Okręgu Przemysłowego w dobie transformacji, [w:] Przemyst w procesie globalizacji, red. Z. Zioło i Z. Makieła, Prace Komisji Geografii Przemysłu PTG, nr 6, Warszawa-Kraków, s. 59-66

Pukowska-Mitka M., Tkocz M. 1992, Restrukturyzacja górnictwa węgla kamiennego w woj. katowickim, [w:] Geografia przemystu w warunkach nowego systemu gospodarowania, COMSN, Komisja Geografii Przemysłu PTG, Kraków, s. 140-154

Plany dostęu do zasobów węgla kamiennego w latach 2004-2006 oraz plany zamknięcia kopalń w latach 2004-2007, 2004, Ministerstwo Gospodarki i Pracy, Warszawa

Rocznik statystyczny kopalń 1991, Państwowa Agencja Węgla Kamiennego, Katowice

Riley R., Tkocz M. 1998, Coal mining in Upper Silesia under communism and capitalism, European Urban and Regional Studies, v. 5, nr 3, s. 217-235

Riley R., Tkocz M. 1999, Local responses to changed circumstances: Coalmining in the market economy in Upper Silesia, Poland, GeoJurnal 48, s. 279-290 
Tkocz M. 1989, Tendencje zmian w strukturze przestrzennej górnictwa węgla kamiennego w woj. katowickim, Geographia. Studia et Dissertationes, t. 13, Katowice, s. 79-97

Tkocz M. 1996, Funkcjonowanie kopalń wegla kamiennego w warunkach ksztaltowania się gospodarki rynkowej, [w:] Wplyw procesów transformacji gospodarki narodowej na funkcjonowanie jednostek gospodarczych i ukladów przestrzennych, red. Z. Zioło, Warszawa-Kraków, s. 60-68

Tkocz M. 1998, Górnictwo węla kamiennego w nowych warunkach gospodarowania, „Przegląd Geograficzny", t. LXX, z. 1-2, s. 69-85

Tkocz M. 2001, Restrukturyzacja przemystu regionu tradycyjnego, Wydaw. Uniwersytetu Śląskiego, Katowice

Zabierowski J. 1996, Wybrane problemy restrukturyzacji polskiego górnictwa wegla kamiennego, „Wiadomości Górnicze”, nr 3, s. 5-9

\section{Effects of hard coal mining restructuring in Poland}

This paper presents changes in the functioning of hard coal mining in Poland in the period of development of free market economy, i.e. after 1989. During this period some attempts were made to bring the coal mining to remunerativeness. Five programmes of coal mining restructuring were implemented. Their main aim was the reduction of excessive production capacities. 23 coal mains were closed down in the period 1989-2003, especially in the northern and eastern parts of the coal basin, which include the areas where coal exploitation was the longest and coal resources are located under considerably urbanised areas, often within safety pillars (Bytom, Chorzów, Gliwice, Zabrze, Będzin, Dąbrowa Górnicza, Sosnowiec). As a consequence, coal production fell from 177.4 million tonnes to 100.5 million tonnes and the employment decreased from 415.7 thousand to 135.7 thousand. An organisational structure is represented by three coal syndicates: Katowice Capital Group with 8 coal mines, Coal Campaign with 23 coal mines and Jastrzębie Coal Company with 5 coal mines. 